\title{
The Finnish Team Academy model: implications for management education
}

\author{
Abstract \\ This article explores an innovative model of management education, the Team Academy \\ based in Finland, in which teams of learners create and operate real enterprises, supported by \\ coaches. The contributions of the article are to provide insights into how the Team Academy \\ works, and to review its implications for theories of management learning and educational \\ design. Based on a case study of the Team Academy model we argue that management \\ education programmes need to be construed as artificially-created learning environments, and \\ specifically as `micro-cultures’ - local contexts in which pedagogical and cultural practices \\ coalesce. The concept of a micro-culture can bring together four main attributes of learning \\ environments (social embeddedness, real-worldness, identity formation and normative). \\ Construing learning environments in this way has likely important implications for the theory \\ and practice of management learning and education, since a micro-culture is a complex, \\ emergent phenomenon that is not necessarily controllable or transferable.
}

\section{Key words}

Micro-culture; learning environment; collective learning; dialogue; entrepreneurial learning; experiential learning. 


\section{Introduction}

'If you really want to see the future of management education you should see Team Academy.' Peter Senge (video message for the Team Academy $15^{\text {th }}$ anniversary

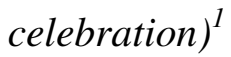

The design of programmes of management education has engaged the attention of many scholars, notably through debates about the relevance and effectiveness of business schools and MBA programmes (Gold, Thorpe, and Mumford 2010, Hay and Hodgkinson 2008, Khurana 2007, Khurana and Snook 2011, Legge et al. 2007, Mintzberg 2004, Pfeffer and Fong 2002, Thursfield 2008, Warhurst 2011); alternative forms of organising management education (Beirne and Knight 2007, Beyes and Michels 2011, Reedy and Learmonth 2009, Reynolds 2000); pedagogical methods and designs such as experiential learning (Kayes 2002), problem-based learning (Hallinger and Lu 2011) and case teaching (Griffith 1999); and the design of entrepreneuership education (Collins et al. 2006, Fletcher and Watson 2007, Pittaway and Cope 2007). The need for new thinking is emphasised by Collins et al. (2006: 352), who have called for `a radical and emergent view of what constitutes a programme curriculum and how learning environments... may be created'.

This article addresses Collins et al.'s call, specifically by questioning how learning environments are understood, based on exploration of an innovative model of management education that has hitherto not, to the best of our knowledge, been analysed in the management learning literature. The model with which this article is concerned is the Team 
Academy, founded in 1993 at JAMK² University of Applied Sciences in Jyväskylä, Finland. It is a model in which teams of learners create and operate real enterprises which the learners themselves own and control (Heikkinen 2003, Leinonen et al. 2004, Partanen et al. 2008). This contrasts with designs that seek to simulate such learning (Pittaway and Cope 2007), or which involve vocational training in businesses that are owned and controlled by educational institutions (e.g. Alexander 2007). The fact that the enterprises created by learners are both real, operating in the open market economy, and owned by the learners themselves, is regarded as central to the Team Academy's capacity for developing skills of management, leadership and entrepreneurship ${ }^{3}$. For example, it makes a significant difference to students' psychological and emotional engagement in these enterprises, and gives them a level of responsibility far beyond that which vocational training entails. The Team Academy model, which is described in more detail below, also incorporates other innovative features; for example it eschews formal teaching, classrooms and curricula. Its emphasis is primarily on team learning in the terms defined by Senge (1990: 236) ('the process of aligning and developing the capacity of a team to create the results its members truly desire') through developing skills of dialogue (Isaacs 1999). The model is employed both as the basis of an undergraduate degree programme in Business Administration and for post-experience leadership training.

The questions we asked were; a) how does the Team Academy model work? b) what is its feasibility for a higher education context outside the host nation? By addressing those questions through an exploratory case study approach we aim to provide insights into the Team Academy model, which is of inherent interest to the field of management learning and merits being more widely known; and to review its implications for theories of the design of management education. Specifically, the Team Academy highlights the need to take into 
account contextual, and particularly micro-contextual, features in order to understand how the model works. We argue that educational programmes need to be construed as artificiallycreated learning environments, and specifically as `micro-cultures’ - local contexts in which pedagogical and cultural practices coalesce. Hence curricula and pedagogical practices (e.g. methods of teaching, learning and assessment) found in such a context may function both to pursue explicit educational objectives and to promote or sustain the micro-culture. This has implications for the design and effectiveness of learning environments for management education.

In the next section we review the management learning literature concerning 'learning environments' highlighting four key attributes (social embeddedness, real-worldness, identity formation, normative) that have been emphasised by previous researchers. We then describe the research context before setting out our methodology. Our findings relating to the Team Academy's explicit pedagogy are complemented by an innovative `outsider-insider' dialogue that highlights the Academy's micro-cultural features. Finally, we show how the four attributes identified in the literature review can be synthesised through the concept of a micro-culture and we comment on implications of this concept for the theory and practice of management learning and education.

\section{Background}

While the design of management education receives much attention, the literature is characterised by disparate themes that lack a coherent conceptual approach (Armstrong and Fukami 2009). For example, the term 'learning environment' appears explicitly and 
repeatedly in the field of management and entrepreneuership education (Collins et al. 2006, Hallinger and Lu 2011, Jones et al. 2006, Lidón et al. 2001, Pittaway and Cope 2007). Collins et al. (2006) refer to notions of a collaborative, peer-learning environment and to a co-learning environment, Hallinger and Lu (2011: 279) are concerned with `a more active and productive learning environment', and Pittaway and Cope (2007: 212) declare their interest in 'how simulations can develop learning environments', including in their data student evaluations of the learning environment. Although reference is made to various theoretical perspectives (for example Legge et al. 2007, Thursfield 2008), none of these authors offers a definition or theory of learning environments. The scale or level of analysis considered also varies; for example from a simulation within a programme (Romme 2003), to a programme itself (Pittaway and Cope 2007), to a programme plus its institutional context (Reedy and Learmonth 2009).

This lack of conceptualisation of learning environments is puzzling. We therefore aim to address this lack of clarity in this article. To begin with we highlight the four attributes and related features of learning environments alluded to above, summarised in Table 1 and discussed in detail below.

\section{INSERT TABLE 1 ABOUT HERE}

Social embeddedness: The first attribute concerns the socially embedded, collective nature of learning, which is central to many researchers' thinking (for example, Pittaway and Cope, 2007). Johnson et al. (1998) and Prince (2004) argue that collaborative and cooperative learning are fundamental to higher education. Based on the principle that learning is socially situated and socially constructed, there is considerable emphasis on pedagogical principles 
and practices that are designed to support collective learning (Fenwick 2008, Rowe 2008). Vygotsky's social learning theory (Vygotsky 1994) is cited as a major influence (Griffith 1999, Hallinger and Lu 2011, Johnson et al. 1998, Jones et al. 2006). For example, Griffith (1999: 344) employs Vygotsky directly by advocating a shift away from a reliance on traditional, teacher-led educational processes towards creating zones of proximal development.

Real-worldness: Several researchers who advocate collective learning do so on the basis of a different principle, which is that a learning environment should approximate or simulate the real world of work. Hence real-worldness provides the second of the four attributes. Fletcher and Watson (2007: 13) advocate a relational approach to entrepreneurship education based on 'the extent to which business ideas tend to be developed in relationship to other people'. Collins et al. (2006: 338) refer to the view that 'the traditional business school model is antiintuitive to the way that entrepreneurs learn in the real world'. Several researchers consider how to design such an environment- for example Pittaway and Cope's (2007: 214) model of 'features required when simulating entrepreneurial learning' - and often emphasise forms of experiential learning and action learning in order to enhance the engagement of the learner (Beard and Wilson 2006, Kayes 2002, Kolb 1984, Lìdon et al. 2001, Pittaway and Cope 2007, Reynolds 2009). Hallinger and Lu (2011: 294) refer to creating `an active, engaging learning environment through the use of what Edgerton (2001) termed "pedagogies of engagement"”, including problem-based learning. An important feature is that risk is acknowledged to be attendant upon real-world learning. Pittaway and Cope (2007: 213), for example, talk of `the creation of an uncertain and ambiguous context encouraging students to step outside taken-for-granted assumptions', thereforeore highlighting the need for 
psychological safety in the learning environment (Beirne and Knight 2007, Conklin et al. 2012, Pittaway and Cope 2007).

Identity formation: The third attribute derives from emphasis on the development of identity as an outcome for the individual learner (Hay and Hodgkinson 2008, Khurana and Snook 2011, Petriglieri and Petriglieri 2010, Warhurst 2011). Just as significant as the acquisition of disciplinary knowledge, if not more so, is the development of personal and professional identity. Hay and Hodgkinson (2008: 30) refer to an `enhanced sense of self' as one of three broad outcomes of MBA studies, and characterise the learning gained through an MBA as transformative (Mezirow 1991). Khurana and Snook consider contemporary business schools from a developmental perspective, citing Petriglieri and Petriglieri's (2010) notion of identity workspaces. They say that `education involves not only the acquisition of knowledge but also the acquisition of identity. Our students don't simply learn about, they also learn to be' (Kuhurana and Snook 2011: 360). Warhurst (2011) highlights a key debate between humanist and structuralist conceptualisations of identity; the former concerns the potential for autonomously developing a sense of self, whilst the latter highlights the way identity is seen to be imposed and regulated by external social forces. Whilst the emphasis of several authors cited here is on the former, we note Warhurst's view that these conceptualisations can be bridged and that managers are 'likely to engage in agentic identity-work' (Warhurst 2011: 265).

Normative: Finally, researchers such as Reedy and Learmonth (2009), Reynolds (2000) and Thursfield (2008) highlight that a learning environment is value-based and normative, having an ideological dimension. Reynolds (2000) examines the notion of community as found in educational settings and questions associations often made between community and harmony. 
Specifically, he contrasts the harmonious ideal of a 'pastoral idyll' with a more cosmopolitan reading of community that is characterised by diversity and political action. Thursfield (2008) argues that, whether implicitly or explicitly, business schools condone the pursuit of instrumentality and individualism. Reedy and Learmonth contend (2009: 242) that 'within most business schools... the normative western values of competitive individualism are typically encouraged, in some cases even before students set foot within them'. They discuss alternative forms of organisation (2009: 241) that `pursue very different ends, in different ways from mainstream business corporations', suggesting that such organisations could lead to a re-think about the way business schools are organised. Many researchers advocate a critical pedagogy approach in order to explore the ideological dimension not only of business but also of the learning environment itself (Beyes and Michels 2011, Cunliffe 2009, Cunliffe and Linstead 2009, Currie and Knights 2003, Fenwick 2005, Reynolds 1999).

Based upon this review we surmise that any artificially-constructed face-to-face learning environment will in principle possess all four attributes, but that educational designs do not necessarily acknowledge these attributes or utilise them intentionally or overtly. We will return to the four attributes when we review our portrayal of the Team Academy. Next we describe the context in which the Team Academy operates before addressing our methodology.

\section{Research Context}

The Team Academy is based at JAMK University of Applied Sciences in Jyväskylä, Finland's seventh largest city, located approximately 270 kilometres north of Helsinki. 
JAMK is a polytechnic within the dual system of higher education in Finland, 'in which polytechnics represent a practically oriented alternative for traditional university education' (Leinonen et al. 2004: 15). The Team Academy dates from 1993 when Johannes Partanen, a marketing lecturer who had become disillusioned with the traditional lecture-based approach to business education, advertised for students who wished to go on a trip around the world. Those who replied were invited to raise the necessary funds by creating enterprise projects. The venture was successful, and Partanen went on to build the approach into a whole degree in Entrepreneurship Development for the award of Bachelor of Business Administration (BBA) (for the credit structure see Leinonen et al. 2004). In essence the degree requires student teams to create and run their own enterprises, in the form of independent co-operative companies, for three and a half years (source: JAMK University 2010). The Academy has produced over six hundred graduates since 1993, and its website states (Team Academy 2011) that:

$91 \%$ of students are employed within 6 months of graduation; $37 \%$ of students launch their own business within 6 months of graduation; $47 \%$ of students are still entrepreneurs 2 years after graduation; 150 completed projects for various companies; $10 \%$ of projects have revenue of over 10,000 EUR.

By comparison, according to JAMK University $(2011)^{4}$, only four per cent of graduates from other corresponding units in Finnish universities of applied sciences become entrepreneurs. In addition to its undergraduate activity, approximately two hundred people participate annually in commercial adult education programmes that use Team Academy principles to teach leadership and coaching. 
The Team Academy is funded $100 \%$ by the Finnish government and has an annual budget of $0.75 €$ million. Finnish students receive a grant of approximately $300 €$ per month (source: Kela 2010) ${ }^{5}$, and there are no student fees as all formal education in Finland is free (source: Ministry of Education and Culture, no date). The Academy can be considered to make a contribution to the Finnish economy through taxation on the businesses it has created; for example the combined amount of tax revenue generated to society from business activities carried out by the team companies operating within Team Academy in 2009 was calculated to be $0.33 €$ million, from a total revenue of $1.5 €$ million (source: Team Academy 2011), equating to nearly half the annual cost of the student grants ${ }^{6}$.

The approach has proved influential within Finland and internationally. Nine Finnish universities make use of Team Academy methods to some extent. For example, BBA programmes at the ProAkatemia of Tampere University of Applied Sciences operate in team companies for two and a half years after a first year of basic studies (source: Proacademy, no date). Mondragòn University in Spain became the first institution outside JAMK to develop a full degree programme on Team Academy principles (commencing 2009), and agreement was reached in 2010 to found a Team Acadmy at the University of Debrecen in Hungary (source: City of Jyvaskyla 2010). Other commercial offshoots of the Team Academy exist in France and Holland.

Finally, the Team Academy's success has been recognised both locally and nationally. It was designated an `Education Center of Excellence’ by Finland's Ministry of Education in 2000, and a centre of excellence in entrepreneurship by the Minister of Trade and Industry in 2008 (source: JAMK University 2011). Most prestigiously, in 2010 founder Johannes Partanen 
received the 'Opetusneuvoksen' title ${ }^{7}$, the highest civic honour in Finland, for his services to education (source: Partus Ltd 2010).

\section{Research Method}

This paper adopts a naturalistic research philosophy (Lincoln and Guba 1995); accordingly, it develops an interpretive account based on qualitative data. Specifically, it takes an exploratory case study approach. Case study is defined by Hartley (2004: 323) as `a detailed investigation, often with data collected over a period of time, of phenomena, within their context'. The Team Academy represents a paradigmatic case (Flyvbjerg 2006) because, while the approach has been adopted elsewhere, Jyväskylä is the original and principal instance. This study is exploratory because it was concerned with asking `open questions to discover what is happening and gain insights about a topic of interest' (Saunders et al. 2012: 171). The case study also includes a descriptive dimension (Saunders et al. 2012), in that it seeks to provide an accurate and informative profile of the Team Academy model.

Initially, [Authors A \& B] studied the Team Academy through a teaching and learning project funded by their institution. The questions posed were: a) how does the Team Academy model work? b) what is its feasibility for a higher education context outside the host nation - in other words, how likely was it that the model could be transferred successfully into another context? Those questions were pursued through exposure to the Team Academy model in a variety of ways, yielding multiple sources of data as is appropriate in a case study approach. Notably, in November 2009 [authors A and B] travelled to Finland to take part in a 'Learning Expedition' - a three-day programme designed to 
provide an experiential introduction to the Team Academy and its model hosted by students and staff in Jyväskylä. This enabled us to gather data through immersion (Saunders et al. 2012: 342) as participant-observers (Watson 1996) during the Learning Expedition, and through conversation with people including the founder of the Team Academy, its coaching staff and students. Observations and reflections were recorded through contemporaneous and post hoc note-taking. Documentary data, such as powerpoint slides and Team Academy publications used during the Learning Expedition, were also collected.

Approximately six months later, also as part of the teaching and learning project, a coach and three graduates from the Team Academy were invited to facilitate introductory workshops for the UK institution's students, staff and interested external parties. [Authors A \& B] organised and attended these workshops. Observations and reflections were again captured through note-taking. These visits were complemented by contact with the Team Academy and its international coach network over approximately eighteen months (starting in the summer of 2009) by e-mail, Skype and face-to-face communication. A considerable breadth and depth of data were therefore accumulated over time from a variety of sources including direct experience, observation, conversations and documents.

Responding to the question about the feasibility of the Team Academy for a higher education context outside the host nation, the internal report for the institutional teaching and learning project concluded that the model worked integrally as a coherent whole. We queried whether it could be transferred in a piecemeal or partial way; modifications, however rational or necessary they appeared, could undermine the success of the model. An example was the likelihood that student ownership of businesses would be discarded in other contexts due to a 
host institution's insurance and risk management requirements; yet this would remove a dynamic that lies at the heart of the Team Academy.

In order to probe further and address more fully the research question about how the Team Academy model worked, we used the data specified above to produce a detailed narrative account that aimed both to represent the Team Academy model reliably and to reflect the cultural features that had been striking during the visit, paying attention to its language, symbols and practices.

This sense-making process began during the Learning Expedition and continued over approximately two years. Following Miles and Huberman (1994), this process was iterative and involved three activities; data reduction (sifting through notes and documentation, selecting themes and material), data display (drafting narratives), and conclusion drawing/verification (reviewing the authenticity of those narratives, especially by collaborating with [Author C], principally via email but also through one face to face meeting, to check the accuracy of, and deepen our understanding of, the model). [Author C] brought first-hand experience of the Team Academy both as a graduate of the Team Academy degree programme and through his subsequent role as a Team Academy coach; he also authored some of the documentary data that was gathered (e.g. Exhibit 2, reproduced below). This process allowed for `theory development which is grounded in empirical evidence' (Hartley 2004: 329) in relation to the theme of learning environments.

Two complementary and contrasting accounts were produced. The first presents the chief features Team Academy model as a pedagogy, comprising its espoused curriculum and methods of teaching, learning and assessment. The second, which takes the innovative form 
of an 'outsider-insider' dialogue, reflects the lived experience of the Team Academy and highlights the micro-cultural features of its learning environment. The dialogic form allows similarities and tensions between the outsider and insider accounts to be presented without being resolved, and to this extent it may said to represent an example of the co-creation of knowledge (Antonacopoulou 2009).

With regard to the validity of interpretive research, Denzin and Lincoln (1998) emphasise that relevant concerns are for trustworthiness and authenticity. According to Lincoln and Guba (1985), trustworthiness comprises credibility, transferability, dependability and confirmability; which can be addressed respectively through a member check, thick description, an audit trail, and triangulation. The criterion of credibility from a `member check' is especially important as it supports the descriptive accuracy and authenticity of our account; this has been addressed through incorporating the perspective of a Team Academy 'insider'. Thickness of description (transferability) has been promoted by developing the accounts iteratively over time, and by producing both descriptive and interpretive accounts. The latter allows different voices to be heard, as the dialogue will show. For confirmability, the present section of the paper provides a form of audit trail commensurate with the length of this article. Finally, with regard to dependability, the fact that it is based on multiple sources of qualitative data (Robson 2002), as described above, allows for a degree of data triangulation (Saunders et al. 2012: 179). For example, experiential data gathered by [Authors A and B] could be compared with documents, with the views of Team Academy staff and students, and with [Author C's] account.

Whilst acknowledging that Lincoln and Guba's four criteria for validity 'can never be satisfied to the extent that the trustworthiness of the inquiry could be labelled as unassailable' 
(Lincoln and Guba 1985: 329), we maintain that our study satisfies the four criteria to an extent sufficient to support our findings.

\section{Findings}

\section{Pedagogy of the Team Academy}

Heikkinen (2003) and Leinonen et al. (2004) suggest that the Team Academy applies the ideas of Senge and others on organisational learning; primarily team learning, which is one of the five 'disciplines' of the learning organisation (Senge 1990), dialogue (Isaacs, 1999) and the knowledge creation theories of Nonaka and Takeuchi (1995). However, it was emphasised by Team Academy staff that its educational philosophy and pedagogy emerged through practice, and were not derived from theory. Some conceptual labels that are applied in publications about the Academy - for example, Leinonen et al. (2004: 35) say that its philosophy is 'based on a constructive-humanistic learning concept' - are acknowledged to be retrospective classifications, used because they have a good fit with practices that have been created through action. This underscores our desire to elucidate the way the model works in practice, and to be wary of post-hoc rationalisations.

The model is based on a fundamental belief that management is learnt by being in business. In contrast to many educational institutions' attempts to simulate workplaces in order to render the student experience more `real', the Team Academy turns the institution into a workplace from which education is an integral output. In order to realise this, learners create and run real businesses. The fact that these are fully owned and controlled by the students themselves appears genuinely distinctive. For example, a separate funded project [Author A, 
Author B, Colleague X, and Colleague Y], (2011) established that while enterprise education is widespread in Europe, the award of credit towards a degree for student-run business is rare, and ownership of businesses by students themselves was found only in the Team Academy and its derivatives.

Another significant feature of the model is the emphasis on the team as the fundamental unit, reflecting Senge's (1990: 233) emphasis on team learning. The team not only provides the primary structure by in which learners are organised, but also the primary ethos that guides behaviour (nevertheless, degrees are still individual awards); hence learners are known as 'teampreneurs'. This represents a departure from the notion of the entrepreneur as an heroic individual that pervades popular culture through, for example, media shows found in many countries in which would-be entrepreneurs pitch their ideas to a panel of successful entrepreneurs $^{8}$. The Team Academy considers that teams make it easier for students to be entrepreneurial because an individual can be more courageous in a team than alone.

In order to create these teams, each intake (presently 60 students per year) is given a team roles questionnaire. Based on the results, the cohort is divided into three 'team company' teams of twenty students each, each of which is allocated space in the warehouse-like layout of the former plywood factory in which the Team Academy is located.

Each team receives two four-hour sessions per week of coaching, called 'Training Sessions' ('Team Academy - trip to the wild west of management education' [no author]: 3-4):

In these sessions, everybody sits round a circle so that they can see one another, and discuss what projects they did, what they have learned, how the finances are going, 
what was last month's turnover, and what can be done to make next month's turnover bigger. From day 1, they have to think and act as entrepreneurs.

During the whole study time each team member participates in approximately 900-1000 hours of such training. Formal classes are not used at all, and short lectures may be used but are rare. The main goal of the coaching process is to develop the team's capacity for dialogue, described by $\operatorname{Isaacs}^{9}$ (1999: 19) as `a means for accessing the intelligence and coordinated power of groups of people'. Team Academy coaches told us that it takes between a year and eighteen months to establish effective dialogue within a team.

From the start of the programme, and for the next three-and-a-half years, each team creates projects and enterprises; team members rotate roles in order to gain varied experiences. It is important to understand, first, that a team is not seeking a single, major business idea. It may operate several projects in parallel - a typical second or third year team has between five and fifteen parallel projects. Second, teams are not expected to develop a business plan before getting into action; instead, there is a strong emphasis on getting out and talking to potential customers. There is no start-up funding, and teams are likely to start with small moneymaking ventures to create their own seed corn before attempting larger scale projects. This is the opposite of many enterprise courses in higher education, in which a business plan is regarded as essential and can even be the chief output. Finally, the typical process for developing enterprises starts not with ideas about business opportunities, but with dialogue about team members' passions and values. It is believed less likely to work for one person to have a business idea and attempt to recruit others to it. 
Students are still expected to read relevant literature, guided by the readings in the Team Academy's catalogue, which is known as the 'book of books'. The ethos is that students' reading is led by business needs and the development of the individual, instead of being prescribed by a teacher. Based on informal monitoring of students' reading, Team Academy coaches claim that its students read more than other students in the same institution. The Academy also rejects the assumption that each student needs to acquire grounding in the typical range of business disciplines that one would find, for example, on most MBA programmes. Instead its principle is that no-one can be, and no-one needs to be, an expert in everything. If skills in (say) accountancy do not exist within the team, then the team can outsource this function. Assessment is through written reflective assignments that emphasise learning from experience, which must make use of texts. There is a self, peer and coach assessment process that is described as $360^{\circ}$ feedback.

In summary, while the Team Academy's pedagogy is sometimes described as an application of ideas about organisational learning, notably those emanating from Senge (1990), its practices have clearly evolved organically over time. Two features that are emphasised above all, and which underpin the entire BBA programme, are the real enterprises coupled with the insistence that these are owned by the students, and the ethos of 'teampreneurship' rather than individualism.

\section{The Team Academy as a micro-culture}

We turn now to our dialogue in order to portray the micro-cultural features of the Team Academy. The 'Outsider' perspective [Authors A and B], in italics, is set alongside the 'Insider' perspective provided by [Author C]. 
$A \& B:$ We are participating in a 'Learning Expedition’ together with another colleague from our institution, two people from Barcelona and one from Sao Paolo. Team Academy students meet us on arrival by train from Helsinki and lead us through the town to a building with a vast factory chimney. This former plywood factory houses the Team Academy (giving rise to the slogan 'from plywood to brain industry'). Its open plan layout and informal dress code reflect what we had previously been told about the pedagogy; there are no classrooms here instead there are offices, meetings rooms and a theatre space.

$\mathrm{C}$ : The 'ownership of space' is extremely important for the team, as it is 'theirs' (as opposed to a classroom that is owned by 'school' in a psychological sense). The allocated office space is called a 'nest' (like a bird's nest).

$A \& B:$ The Team Academy presents itself as an alternative, 'truly different' form of education through its own educational and publicity materials (see Exhibit 1). Exhibit 1 shows how, just as Senge (1990:18) suggests that many organisations have 'learning disabilities', the Team Academy frames traditional methods of management education as problematic and (in intentionally polarised fashion) positions the Academy as offering solutions to these.

\section{INSERT EXHIBIT 1 ABOUT HERE}

A \& B: Symbolic paraphernalia abound. The Team Academy logo depicts two teampreneurs, one supporting the other. The distinctive language includes, as well as 'teampreneurs', 'penguins' (first year students), 'sticky monsters' (university staff who take a bureaucratic, 
rule-bound approach to education) and 'birthgivings' (a format for presentations). 'Leading Thoughts' is a red pamphlet that sets out the philosophy of the Team Academy. Updated each year by Johannes Partanen, the founder, the 'thoughts' are 'based on mutual trust, selfdiscipline and pride in our accomplishments'. The 'five E's' (entertainment, escapism, esthetic (sic), education, esprit - sometimes accompanied by a sixth ‘e’, eroticism) are principles that students are encouraged to incorporate into their activities. The 'rocket model', a colourful diagrammatic representation of the Team Academy curriculum, is displayed on posters and the front covers of notebooks.

C: The sixth 'E' was a joke, really! The Leading Thoughts are reviewed by the whole community each year. So, the students themselves can change them as they wish. The rocket model represents the 'learning path' or 'development of team company' in a simplified way. It is just framework that helps the community to 'speak the same language'. Rocket model pictures are all over the Team Academy - wherever you stand, you can see one! Also, 'The Rocket' is part of Team Academy's metaphors.

A \& B: Our encounters with Team Academy students - not only during the Learning Expedition but also thereafter - support claims for the effectiveness of the approach, in that we perceive them to be relatively more confident, capable and energetic than undergraduates from our own institution, with an impressive ability to take initiative and responsibility.

C: To my personal experience (e.g. as a coach), Team Academy students seem to be more 'energetic’ than other Finnish higher education students. 
$A \& B:$ On our first evening in Jyväskylä we board a coach and are driven out of the town into the darkness at speed, the driver seemingly oblivious to the newly fallen snow. We arrive at a coaching house, warm ourselves by the open fire, and dine on an immense, heartening buffet of traditional Finnish food. After dinner, we are introduced to the wooden-built sauna by the lake, the women first, the men later. The lake is frozen, which means that it isn't safe to cool-down periodically by running from the sauna to the lake and diving into the water. There is an alternative, however. Exit the sauna and lie in the snow outside, making a snow angel. It is strangely delicious to lie on one's back on a fresh blanket of snow that tingles like a frozen sherbet. Meeting in the sauna and daring the icy darkness with these new acquaintances is a ritual that, both literally and metaphorically, removes many inhibitions.

The Team Academy is also replete with stories. On day two of our Learning Expedition, within a circle of low chairs in the seminar room, Johannes Partanen talks of the early days of Team Academy and of the 'sticky monsters' who are its enemies. He tells how, in the mid1990s a team of undergraduates took on as a project the organising of the annual stage of the Finnish rally in Jyväskylä. They took a bold risk; to move the rally from the surrounding forests into the town, thus increasing exposure and participation. It was a great success. As a result the team was awarded the Nokia field telephone used in the rally - an early, and very chunky, form of mobile phone, which Johannes brandishes.

Before starting the Team Academy, Johannes founded his consultancy, Partus Ltd. (which means 'birth'), which remains Team Academy's Adult Education Unit. Partus controls the Team Academy brand and the training of coaches, which is provided through a commercial programme called 'Team Mastery'. In the offices of Partus, which moved to a separate building earlier in 2009, one wall is occupied by a large map of the world. This shows the 
Team Academy's various satellites, from full degree programmes such as at Mondragòn, to outreach activities in Africa and South America.

C: Partus is an independent company and has no control whatsoever over JAMK (and vice versa). Partus Ltd owns the Team Academy trademark and has given JAMK full rights to use the brand for unlimited time. Team Academy full-time coaches are employed by JAMK University of Applied Sciences, not Partus Ltd. Thus, they work 100\% in public sector. They are obliged to do their JAMK work for forty hours a week and are not allowed in any way to work for private sector during that time. Part-time coaches work for Partus Ltd $50 \%$ of their time and 50\% for JAMK. It is important to emphasise that it is the students who own the businesses that they create. Neither Partus nor the Team Academy assumes any financial stake in these enterprises.

$A \& B$ : Various rituals and routines exist. Each year there is a birthday celebration. The central educational ritual of the Team Academy is called 'birthgiving', which refers to the format used by teams for presenting learning to colleagues and others. Often an enactment or a performance but never a Powerpoint presentation, a birthgiving is a creative process, a celebration and a continuation of (rather than the termination of) a learning process.

$\mathrm{C}$ : Birthgiving is formally 'competency demonstration'. But it is normally a presentation where the objective is (or should be) to (1) solve real-life problems or invent something new, (2) learn together.

A \& B: Our Learning Expedition group is tasked with producing its own birthgiving to convey what we have learnt from our exposure to the Team Academy model. We perform it in 
the open theatre space in the factory, to which all students in the building are summoned. Immediately afterwards the audience question us about our enactment and our learning. Insights about our capacity for team working and entrepreneurship are applauded. There is also an inkling of doubt here; are we being rewarded for our insights, or conforming to the Team Academy model? We note a sense of there being a 'way of doing things', into which we are perhaps being acculturated.

C: You might be right?! I have never thought about this in this way... We just run Learning Expeditions so that the participants have to opportunity for themselves to experience how we learn in Team Academy. There is no intentional attempt to make anyone conforming, that is for sure. Interesting observation!

$A \& B:$ We experience the birthgiving as both liberating and limiting, in the sense of being steered towards a form of apparently authentic behaviour. To what extent might such tacit influence exist elsewhere in the model? One of the coaches tells us that if they see students getting too comfortable and spending too much time in the factory, they turn the heating down. The Team Academy ethos is that students should be out meeting customers.

$\mathrm{C}$ : Interesting observation. Being passive is frowned upon, that is right.

$A \& B$ : Being a teampreneur is valued, and regarded as the antithesis of being a `sticky monster'. Enactment of the Leading Thoughts and the '5 e's' is encouraged and expected. They describe Team Academy as a cause: 'Leading thoughts tell us what we are fighting for and why we exist. Coaches of Team Academy and team entrepreneurs should maintain them. ${ }^{10}$ We notice use of terms such as 'spreading the word' ('Team Academy-trip to the 
wild west of management education' [no author]: 8). Is it seeking converts to its cause through 'igniting’ others’ passions and engaging them in the 'fight’’?

C: You are right. In our stories and culture there are 'good guys' and 'bad guys'.

$A \& B$ : Enthusiasm is also expected within this 'can-do' and 'just do it' culture.

C: It is expected. But it is created naturally.

$A \& B:$ The enthusiasm can feel seductive and euphoric. When we hear problems reframed as ‘joyful challenges', and post-experience courses referred to as 'adult entertainment' it almost starts to feel a bit 'happy clappy', with echoes of positive thinking (e.g. Peale 1990).

$\mathrm{C}$ : This has nothing to do with positive thinking. It is just a joke about a language mistake made by our managing director. But, the culture of Team Academy emphasises jokes and having fun. There are small hints of American `positive thinking' movement in Team Academy culture. However, in daily life only rarely do people think that they can `achieve anything'. Real life experiences and observations quickly put end to such thinking.

$A \& B$ : Indeed it would be inaccurate to suggest that 'positive thinking' dominates the Academy. There is plenty of straight-talking and challenge from both peers and coaches. There is also emphasis on having ‘the right attitude’ (Team Academy coach). It is acknowledged that the Team Academy is not for everyone, and that students who don't fit are encouraged to leave at an early stage. As a student says, 'if you don't want to be a team player, go to ordinary university'. 
C: Approximately 10\%-15\% of the students leave before they are graduated. Most of them leave during their first year. This `drop-out' percentage is (to my knowledge) very low when compared to other similar BBA programmes.

$A \& B:$ The identity and boundaries of the Academy are managed actively in other respects. Partanen has sought to avoid interference from JAMK, whether from interference by sticky monsters or encroachment into the Team Academy's autonomy. He positions it as an experimental venture ('a pilot') in order to minimise threat to other departments' territories. Within the Team Academy's seemingly informal system there are differentiated and to some extent stratified roles. Johannes Partanen remained its leader until his retirement in 2011. Coaches form a cohort of staff. Neophyte students are called penguins, denoting their tendency to follow others' lead; those who have learnt the Academy's ways of operating are called teampreneurs. Certain graduates remain involved in the Academy and act as its ambassadors abroad.

$\mathrm{C}$ : The role of the head-coach is stratified. To my experience, there are no hierarchies as such, although in juridical terms there are supervisors, management, etc. In daily life coaches are all equal. Some of the coaches may have more 'power' in certain issues than others because of their experience. The organisational form is a bit like 'adhocracy'. The idea of classical hierarchy seems strange to me in Team Academy context - but there might be an informal one...

\section{Discussion of Findings}


Based on our analysis we argue that the concept of a micro-culture offers a better understanding of how the Team Academy works than a description of its pedagogical design and practices alone. The two complementary accounts illustrate the difficulty of isolating pedagogy from micro-culture; it seems difficult to apprehend the Team Academy without acknowledging the influence of its founder and charismatic leader, its philosophy and history, its symbols, language and rituals, the way it is organised and framed as a 'cause' and the ways in which learners are steered towards becoming 'teampreneurs'. The concept of a micro-culture brings into relief features that seem integral to, and likely to be critical to the effectiveness of, the Team Academy model.

It is also significant that the Team Academy is an emergent phenomenon. It incorporates deliberate design elements but has evolved over time from its origins as a response to Partanen's dissatisfaction with educational orthodoxy. Its micro-culture is accounted for through stories of real events, such as that of the Jyväskylä car rally, more than through theory, and conceptualisations have been applied retrospectively.

It is logical to expect that a micro-culture would be characterised by features such as language, symbols and rituals, as has been illustrated through the case of the Team Academy. For this concept to have specific relevance to learning environments, we propose that the micro-culture of an educational programme will also be characterised by the way the four attributes identified in the literature review are manifested.

Table 2 indicates how the four attributes are reflected in the Team Academy in practice. 
As we interpret it, the first two attributes (social embeddedness and real-worldness) are explicit and significant in the Team Academy's pedagogy, as evident from the case study data. The third attribute (identity formation) is explicit in the sense that it features in explanations by staff and students of how the model works. The extent to which it is an intentional feature of the pedagogical design is debatable. The case study suggests that the language of penguins and teampreneurs, for example, is more likely to be an emergent microcultural phenomenon.

The fourth attribute (normative) is also evident from the dialogue that highlights microcultural features. However, normativity appears not to be attended to intentionally for educational purposes. By this, for example, we mean that critical reflection on the model does not appear to be promoted, even though there is scope for doing so. Thus Senge's notion of 'alignment', which is central to his conception of team learning and occurs (Senge 1990: 234) when `a commonality of direction emerges, and individuals' energies harmonize', could be questioned by applying Reynolds' (2000) critique of community, especially given the prevalence of reference to the Team Academy by its participants as a community. The emphasis on team learning and dialogue invite scrutiny too, given Erhardt's criticism (2011: 87) of the 'pervasive assumption... that more teamwork is always better' and the need, according to Rowe (2008: 41), to address lacunae in collective learning methodologies such as Isaacs' (1999) dialogue. The ‘book of books', a Team Academy student's principal guide to reading, lists many volumes but contains no academic journal articles. Potential issues of power arising from the role of coaches as assessors receive little attention. Emphasis on being positive and enthusiastic brings to mind Reynolds' and Vince's concern (2004: 447) that management education becomes an endeavour in which `individuals have particularly learned 
how to suppress, contain, or neutralize emotions as well as how to focus solely on positive emotions (Hopfl and Linstead 1997)', as well as their concerns (Reynolds and Vince 2004: 443) that the need to do can override concerns to reflect upon and inquire into values and ideology. The Team Academy may represent an example of alternative organisation, but appears not to be one that pursues `very different ends, in different ways from mainstream business corporations' (Reedy and Learmonth 2009: 241). It could even be seen as glorifying the pursuit of private enterprise.

These comments should not be taken in any way as disparaging the Team Academy model, which we believe represents a significant, innovative form of management education that appears to have important social benefits as well as successful educational outcomes. Nor should our comments be read as implying that the Team Academy should adopt a critical pedagogy (e.g. Currie and Knights 2003). The point being made here is that the four attributes are all present in this artificially-created learning environment, and manifested in specific ways that characterise the micro-culture of the Team Academy as a micro-culture. The attributes vary according to the whether or not, and how, they are exploited as opportunities for learning within the programme.

We would expect other programmes to vary similarly across the four attributes. Some artificially-created learning environments might highlight a single attribute or sub-set of attributes, as in the real-world emphasis of Romme's (2003) 'microworld' simulation. In traditional, classroom forms of management education, little explicit attention may be given to any of the attributes. Collective learning may exist only to the extent that it occurs naturally amongst the cohort in question; relevance may be provided intentionally in weak form such as the use of case examples within classroom activities; identity formation may be 
tacit, as in Khurana and Snook’s (2011: 360) comment that `students don’t simply learn about, they also learn to $b e$; and normativity may also be tacit, taking institutional and societal norms for granted. We argue that such a programme still represents a micro-culture, even if its cultural features have not been designed intentionally for educational purposes.

Among the practical implications of this concept of a micro-culture is that management educators may find it helpful to consider what configuration of these four attributes would best serve the aims of the programme in question; and therefore which curricula and pedagogical practices would be congruent with, and most likely to promote, that configuration. The Team Academy model appears to represent a configuration that has coevolved with its particular purposes into highly coherent micro-culture. Equally, management educators may need to be mindful that a micro-culture is a complex, dynamic and emergent phenomenon over which they are likely to have influence, but not total control.

The concept of a micro-culture also has important implications for the transferability of pedagogical practices (Illeris 2009); indeed it brings into question the metaphor of 'transfer', since it is probably more appropriate to talk of a micro-culture being replicated than transferred. Whilst methods used in the Team Academy such as dialogue are applicable in other settings, the model is not something that can be extracted from its context. Thought of as a micro-culture, it exists as a whole and should resist treatment as if comprised of optional, replaceable components. The project to create a version of the Team Academy at Mondragòn University in Spain is potentially a site of great interest for further study of the process of replicating a micro-culture and for cross-cultural comparison. 
In summary, the concept of a micro-culture not only conveys how a learning environment works in practice, but also enables these four attributes to be brought together in such a way as to offer possibilities for both analysis and design for the purposes of management education.

A limitation of this study is that it is based on a single case study, which is often thought incorrectly, according to Flyvbjerg (2006) - to provide no opportunity for generalisation. We regard the Team Academy as a case example that offers an opportunity for inductive theory generation through `building a novel conceptual framework and propositions’ (Ridder et al. 2012: 4). Our findings are put forward not as generalisations that are assumed to be valid for all programmes of management education, but as an advancement in understanding of the nature of learning environments that is offered for debate and testing within the field.

\section{Conclusion}

In response to questions about how the Team Academy model works, and its feasibility for a higher education context outside the host nation, the contributions of this article are to provide in-depth insight into how the Team Academy works this, and to review its implications for theories of management learning and educational design.

The Team Academy appears to represent an inspiring challenge to orthodox ways of organising management education. It claims an impressive track record, according to which it has succeeded in creating an effective and influential context for generating not just learning among its participants but also real new businesses that are making a social and economic contribution. There are both strengths and weaknesses to the model - for example, we have 
indicated a lack of explicit attention to academic literature and to criticality - but it appears that the strengths are considerable, especially for learners who are inclined to operate entrepreneurially. It is an innovation that is of inherent interest to the field of management learning and merits being more widely known.

In the absence of an explicit theory of the design of artificially-created learning environments for management education, this article has developed the concept of a 'micro-culture', a local context in which pedagogical and cultural practices coalesce. This concept is congruent with the emergent, dynamic nature of the Team Academy model and brings together four attributes of learning environments considered important by authors in the field; social embeddedness, real-worldness, identity formation and normative. Curricula and pedagogical practices (e.g. methods of teaching, learning and assessment) found in such a context may function both to pursue explicit educational objectives and to promote or sustain the microculture. This has implications for the design of learning environments within the field of management learning, and for the effectiveness and transferability of management education programmes. 


\begin{tabular}{|c|c|}
\hline Attribute & Examples from literature \\
\hline \multicolumn{2}{|l|}{ Social embeddedness } \\
\hline $\begin{array}{l}\text { 1. Recognises that learning is essentially } \\
\text { socially-embedded; may be informed } \\
\text { explicitly by social constructionist theory } \\
\text { (e.g. Vygotsky 1994). }\end{array}$ & $\begin{array}{l}\text { 1. Johnson et al. (1998); Legge et al. } \\
\text { (2007); Pittaway and Cope (2007); Rowe } \\
\text { (2008); Thursfield (2008) }\end{array}$ \\
\hline $\begin{array}{l}\text { 2. Utilises pedagogical designs and methods } \\
\text { that support collective learning (eg dialogue). }\end{array}$ & $\begin{array}{l}\text { 2. Fenwick (2008); Griffith (1999); } \\
\text { Hallinger and Lu (2011); Isaacs (1999) }\end{array}$ \\
\hline \multicolumn{2}{|l|}{ Real-worldness } \\
\hline $\begin{array}{l}\text { 1. Aims to approximate or simulate the 'real } \\
\text { world' conditions in which learners will } \\
\text { operate. }\end{array}$ & $\begin{array}{l}\text { 1. Baker et al. (2005); Hallinger and Lu } \\
\text { (2011); Romme (2003); Reynolds (2009) }\end{array}$ \\
\hline $\begin{array}{l}\text { 2. Utilises pedagogical designs and methods } \\
\text { that enhance 'real world' experience (eg } \\
\text { experiential and action learning, problem- } \\
\text { based learning). }\end{array}$ & $\begin{array}{l}\text { 2. Collins et al. (2006); Fletcher and } \\
\text { Watson (2007); Gibb (1995); Hallinger } \\
\text { and Lu (2011); Pittaway and Cope } \\
\text { (2007); Warhurst (2011) }\end{array}$ \\
\hline $\begin{array}{l}\text { 3. 'Real world' conditions entail risk; measures } \\
\text { for psychological safety enhance learning }\end{array}$ & $\begin{array}{l}\text { 3. Beirne and Knight (2007); Conklin et al. } \\
\text { (2012); Pittaway and Cope (2007) }\end{array}$ \\
\hline \multicolumn{2}{|l|}{ Identity formation } \\
\hline $\begin{array}{l}\text { 1. Involves acquisition of identity, an enhanced } \\
\text { sense of self and/or membership of a } \\
\text { community. This may be valued and actively } \\
\text { supported through the curriculum. }\end{array}$ & $\begin{array}{l}\text { 1. Hay and Hodgkinson (2008); Khurana } \\
\text { and Snook (2011); Petriglieri and } \\
\text { Petriglieri (2010); Warhurst (2011) }\end{array}$ \\
\hline \multicolumn{2}{|l|}{ Normative } \\
\hline $\begin{array}{l}\text { 1. A learning environment has an ideological } \\
\text { dimension, with norms and values. } \\
\text { Educational methods serve both a } \\
\text { pedagogical purpose (meeting explicit } \\
\text { learning outcomes) and an ideological } \\
\text { purpose (maintaining the 'culture'). }\end{array}$ & $\begin{array}{l}\text { 1. Beyes and Michels (2011); Reedy and } \\
\text { Learmonth (2009); Reynolds (2000); } \\
\text { Reynolds and Vince (2004) }\end{array}$ \\
\hline $\begin{array}{l}\text { 2. This duality of purpose can be explored } \\
\text { reflexively by participants, especially within } \\
\text { a critical curriculum. }\end{array}$ & $\begin{array}{l}\text { 2. Beyes and Michels (2011); Cunliffe } \\
\text { (2009); Cunliffe and Linstead (2009); } \\
\text { Currie and Knights (2003); Fenwick } \\
\text { (2005); Reynolds (1999) }\end{array}$ \\
\hline
\end{tabular}

Table 1: Four attributes of learning environments 


\begin{tabular}{|l|l|}
\hline Attribute & The Team Academy \\
\hline Social embeddedness & $\begin{array}{l}\text { Identified as `being based on a constructive-humanistic learning } \\
\text { concept' (Leinonen } \text { et al. 2004: 35). Methods of collective } \\
\text { learning - team learning, dialogue and collaborative assessment } \\
\text { - are central in practice. }\end{array}$ \\
\hline Real-worldness & $\begin{array}{l}\text { Use of real, student-owned and controlled enterprises. } \\
\text { Experiential learning and action learning are prominent. Risk is } \\
\text { heightened by the facts that enterprises are real and student- } \\
\text { owned; coaching and team learning enhance psychological } \\
\text { safety. }\end{array}$ \\
\hline Identity formation & $\begin{array}{l}\text { Membership acquired through participation (initially as } \\
\text { 'penguins', then acquiring the identity of 'teampreneur'). A } \\
\text { distinctive language, team orientation, dialogue and } \\
\text { entrepreneurial behaviour symbolise membership of this } \\
\text { community as well as supporting the achievement of overt } \\
\text { learning outcomes. }\end{array}$ \\
\hline Normative & $\begin{array}{l}\text { Framed as a `cause’ in which `good guys' do battle with `bad } \\
\text { guys' (i.e. sticky monsters); presented as benign but can be } \\
\text { perceived as a subtle means of regulation that recruits learners to } \\
\text { the `cause'; hence educational methods also function as } \\
\text { ideological practices. However, little evidence of criticality with } \\
\text { regard to the explicit curriculum, or reflexivity about the micro- } \\
\text { culture. }\end{array}$ \\
\hline
\end{tabular}

Table 2: The Team Academy mapped onto the four attributes of a learning environment 


\begin{tabular}{|l|l|}
\hline Problem & Solution \\
\hline $\begin{array}{l}\text { No education how to operate in a team or } \\
\text { just artificial team exercises }\end{array}$ & $\begin{array}{l}\text { Real teams with real-life problems to } \\
\text { tackle with }\end{array}$ \\
\hline $\begin{array}{l}\text { No connecting to real world; just theories } \\
\text { or simulations (e.g. case studies) }\end{array}$ & Real projects and real customers \\
\hline $\begin{array}{l}\text { Tests (e.g. examinations or study papers) } \\
\text { focus mainly on remembering 'facts' and } \\
\text { pleasing the professor or teacher }\end{array}$ & $\begin{array}{l}\text { Skill tests with 360 assessment, real-life } \\
\text { situations where real customer gives } \\
\text { candid feedback; holistic assessment an } \\
\text { development }\end{array}$ \\
\hline $\begin{array}{l}\text { Ethnocentric education; usually } \\
\text { 'americanized' views of management and } \\
\text { entrepreneurship }\end{array}$ & $\begin{array}{l}\text { Build a learning architecture where the } \\
\text { teachers and students themselves create a } \\
\text { culture and views that they want and } \\
\text { believe in }\end{array}$ \\
\hline $\begin{array}{l}\text { No reflection and just individual rote } \\
\text { learning }\end{array}$ & $\begin{array}{l}\text { Dialogue and team learning where both } \\
\text { teachers and students reflect on things } \\
\text { learn and share ideas }\end{array}$ \\
\hline $\begin{array}{l}\text { Focus on 'getting the papers' or } \\
\text { graduating as MBA' }\end{array}$ & $\begin{array}{l}\text { Focus on business results and individual } \\
\text { development; papers just prove that you } \\
\text { have done your job well and have the } \\
\text { competencies the school claims }\end{array}$ \\
\hline $\begin{array}{l}\text { Lots of theory, no application of theory } \\
\text { into practice }\end{array}$ & $\begin{array}{l}\text { Continuous application of theory into } \\
\text { practice; flexible theory program for each } \\
\text { student }\end{array}$ \\
\hline $\begin{array}{l}\text { The school claims to educate leaders and } \\
\text { managers but its activities do not include } \\
\text { real-life leadership work, just fancy talk } \\
\text { about leadership }\end{array}$ & $\begin{array}{l}\text { Various intraorganizational leadership } \\
\text { positions, leadership positions in a team, } \\
\text { leadership positions in projects, personal } \\
\text { responsibility on customers }\end{array}$ \\
\hline $\begin{array}{l}\text { Everybody learns the same and } \\
\text { management }\end{array}$ & $\begin{array}{l}\text { Many ways of learning, rich culture filled } \\
\text { with various learning possibilities; } \\
\text { individual learning paths and flexibility }\end{array}$ \\
\hline
\end{tabular}

Exhibit 1: Problems with traditional management education and our solutions to them (Partus factfile October 2010) 


\section{References}

Alexander, M (2007) Reflecting on changes in operational training in UK hospitality management degree programmes. International Journal of Contemporary Hospitality Management 19(3): 211-220.

Antonacopoulou, E (2009) Impact and scholarship: Unlearning and practising to co-create actionable knowledge. Management Learning 40(4): 421-430.

Armstrong, SJ and Fukami, CV (eds) (2009) The SAGE Handbook of Management Learning, Education and Development. London: Sage

Author A, Author B, Colleague X and Colleague Y (2011). An exploration of the use of student-run, real businesses in the South East Region, the UK and internationally for all or part of the award of a university degree The Higher Education Entrepreneurship Group.

Baker, AC , Jensen, PJ and Kolb, DA (2005) Conversation as experiential learning. Management Learning 36(4): 411-427.

Beard, C and Wilson, JP (2006) Experiential Learning: A Best Practice Handbook for Educators and Trainers (Second ed.). London: Kogan Page.

Beirne, M and Knight, S (2007) From community theatre to critical management studies. Management Learning 38(5): 591-611.

Beyes, T and Michels, C (2011). The production of educational space: Heterotopia and the business university. Management Learning, 42(5): 521-536.

City of Jyvaskyla (2010) Agreement for academic cooperation between Debrecen and Jyväskylä. Available at:

http://www.jyvaskyla.fi/international/news/educational_agreement_between_debrecen_ and_jyvaskyla.

Collins, LA, Smith, AJ and Hannon, PD (2006) Applying a synergistic learning approach in entrepreneurship education. Management Learning 37(3): 335-354

Conklin, J, Kyle, T and Robertson, C (2012) The essential transformation: How Masters students make sense and learn through transformative change Management Learning (online, doi:10.1177/1350507612439279). 
Cunliffe, AL (2009) The philosopher leader: On relationalism, ethics and reflexivity—a critical perspective to teaching leadership. Management Learning 40(1): 87-101.

Cunliffe, AL and Linstead, SA (2009) Introduction: Teaching from critical perspectives. Management Learning 40(1): 5-9.

Currie, G and Knights, D (2003) Reflecting on a critical pedagogy in MBA education. Management Learning 34(1): 27-49.

Denzin, NK and Lincoln, YS (eds) (1998) The Landscape of Qualitative Research. London: Sage

Edgerton, R (2001) Education White Paper. Report prepared for the Pew Charitable Trusts, Pew Forum on Undergraduate Learning. Washington, DC.

Erhardt, N (2011) Is it all about teamwork? Understanding processes in team-based knowledge work. Management Learning 42(1): 87-112.

Fenwick, T (2005) Ethical dilemmas of critical management education. Management Learning 36(1): 31-48.

Fenwick, T (2008) Understanding relations of individual—collective learning in work: A review of research. Management Learning 39(3): 227-243.

Fletcher, DE and Watson, TJ (2007) Entrepreneurship, management learning and negotiated narratives: 'Making it otherwise for us - otherwise for them'. Management Learning 38(1): 9-26.

Flyvbjerg, B (2006). Five misunderstandings about case-study research. Qualitative Inquiry 12(2): 219-245.

Gold, J, Thorpe, R and Mumford, A (eds) (2010) Gower Handbook of Leadership and Management Development (5th ed.). Aldershot: Gower.

Griffith, W (1999) The reflecting team as an alternative case teaching model. Management Learning 30(3): 343-362.

Hallinger, P and Jiafang Lu (2011) Assessing the instructional effectiveness of problembased management education in Thailand: A longitudinal evaluation. Management Learning 42(3): 279-299.

Hartley, J (2004) Case study research, in Cassell, C and Symon, G (eds) (2004) Essential Guide to Qualitative Methods in Organizational Research. London: SAGE Publications: 323-333.

Hay, A and Hodgkinson, M (2008) More success than meets the eye-a challenge to critiques of the MBA. Management Learning 39(1): 21-40. 
Heikkinen, H (2003) Team Academy: A story of a school that learns. Development and Learning in Organizations 17(1): 7-9.

Hopfl, H and Linstead, S (1997) Introduction: Learning to feel and feeling to learn, emotion and learning in organizations. Management Learning 28(1): 5-12.

Illeris, K (2009) Transfer of learning in the learning society: How can the barriers between different learning spaces be surmounted, and how can the gap between learning inside and outside schools be bridged? International Journal of Lifelong Education 28(2): 137-148.

Isaacs, WN (1999) Dialogue and the Art of Thinking Together. New York: Doubleday. JAMK University (2010) Degree Programme in Entrepreneurship Development, Team Academy. Available at:

http://www.jamk.fi/english/forstudents/studyguide/degreeprogrammes/generaldescripti ons/degreeprogrammesinstructioninfinnish/entrepreneurshipdevelopment.

JAMK University (2011) Creating Competence. Available at: http://www.jamk.fi/english/aboutus.

Johnson, DW, Johnson, RT and Smith, KA (1998) Cooperative learning returns to college: What evidence is there that it works? Change: The Magazine of Higher Learning 30(4): 26-35.

Jones, C, Connolly, M, Gear, A and Read, M (2006) Collaborative learning with group interactive technology. Management Learning. 37(3): 377-396.

Kayes, DC (2002) Experiential learning and its critics: Preserving the role of experience in management learning and education. Academy of Management Learning and Education 1(2): 137-149.

Kela (2010) Available at: http://www.kela.fi/in/internet/english.nsf/NET/081001131300IL?OpenDocument,

Khurana, R (2007) From higher aims to hired hands: The social transformation of American business schools and the unfulfilled promise of management as a profession. Princeton, NJ: Princeton University Press.

Khurana, R and Snook, S (2011) Commentary on 'A Scholar's Quest' - Identity work in business schools: From Don Quixote, to dons and divas. Journal of Management Inquiry 20(4): 358-361

Kolb, D (1984) Experiential Learning: Experience as the Source of Learning and Development. New Jersey: Prentice-Hall. 
Legge, K, Sullivan-Taylor, B, and Wilson, D (2007) Management learning and the corporate MBA: Situated or individual? Management Learning 38(4): 440-457.

Leinonen, N, Partanen, J and Palviainen, P (2004) The Team Academy: A True Story of a Community That Learns by Doing. Jyväskylä, Finland: PS-kustannus.

Lidón, I, Rebollar, R and Møller, C (2011) A collaborative learning environment for management education based on experiential learning. Innovations in Education and Teaching International 48(3): 301-312.

Lincoln, Y, and Guba, E (1985) Naturalistic Inquiry. Newbury Park, CA: Sage

Mezirow, J (1991) Transformative Dimensions of Adult Learning. San Francisco: Jossey Bass.

Miles, M, and Huberman, AM (1994) Qualitative Data Analysis (2 ${ }^{\text {nd }}$ ed.). London: Sage Ministry of Education and Culture (no date) Education Policy in Finland. Available at: http://www.minedu.fi/OPM/Koulutus/koulutuspolitiikka/?lang=en.

Mintzberg, H (2004) Managers not MBAs: A Hard Look at the Soft Practice of Managing and Management Development. London: Prentice Hall.

Nonaka, I and Takeuchi, H (1995) The Knowledge Creating Company: How Japanese Companies Create the Dynamics of Innovation. Oxford: Oxford University Press.

Partanen, J, Heikkinen, H, Luukas, U, Keränen, V, Tuohimetsä, T, Collignon, E, Marnacher, L, van der Haegen, C, Collart, R, Neusuess, C and Ruiz, J (2008) A learning exploration Team Academy network: Creating team entrepreneurs for bridging social and cultural divide. Paper presented at the 3rd global SOL forum, 13-16 April 2008, Muscat, Oman.

Partus Ltd (2010) Opetusneuvoksen arvonimen saanut Johannes Partanen astuu uuteen rooliin Available at: http://newsletter.partus.fi/uutiskirje/2010-5/opetusneuvoksenarvonimen-saanut-johannes-partanen-astuu-uuteen-rooliin-\%E2\%80\%93-tiimiaka.

Peale, NV (1990) The Power of Positive Thinking. London: Vermilion.

Petriglieri, G and Petriglieri, JL (2010) Identity workspaces: The case of business schools. Academy of Management Learning and Education 9(1): 44-60.

Pfeffer, J and Fong, CT (2002) The end of business schools? Less success than meets the eye. Academy of Management Learning and Education 1(1): 78-95.

Pittaway, L and Cope, J (2007) Simulating entrepreneurial learning. Management Learning 38(2): 211-233.

Prince, M (2004) Does active learning work? A review of the research. Journal of Engineering Education 93(3): 223-231. 
Proacademy (no date) Available at: http://www.proakatemia.fi/en/.

Reedy, P and Learmonth, M (2009) Other possibilities? The contribution to management education of alternative organizations. Management Learning 40(3): 241-258.

Reynolds, M (1999) Critical reflection and management education: Rehabilitating less hierarchical approaches. Journal of Management Education 23(5): 537-553.

Reynolds, M (2000) Bright lights and the pastoral idyll. Management Learning, 31(1): 67-81.

Reynolds, M (2009) Wild frontiers - reflections on experiential learning. Management Learning 40(4): 387-392.

Reynolds, M and Vince, R (2004) Critical management education and action-based learning: synergies and contradictions. Academy of Management Learning and Education 3(4): 442-456.

Ridder, H-G, Hoon, C and McCandless Baluch, A (2012) Entering a dialogue: Positioning case study findings towards theory. British Journal of Management (online, doi: 10.1111/1467-8551.12000).

Robson, C (2002) Real World Research (2nd edn). Oxford: Blackwell.

Romme, AGL (2003) Learning outcomes of microworlds for management education. Management Learning 34(1): 51-61.

Rowe, A (2008) Unfolding the dance of team learning: A metaphorical investigation of collective learning. Management Learning 39(1): 41-56.

Saunders, MNK, Lewis, P and Thornhill, A (2012) Research Methods for Business Students (6th ed.). London: Pearson/Financial Times Press

Senge, P (1990) The Fifth Discipline: The Art and Practice of the Learning Organization. London: Century Business, Random.

Team Academy - trip to the wild west of management education (no author, no date) Available at: http://www.teamfactory.org/IMG/pdf/Team_Academy-Presentation__english_-_decembre_2008.pdf.

Thursfield, D (2008) Managers' learning in a UK local authority: The political context of an in-house MBA. Management Learning 39(3): 295-309.

Vygotsky, LS (1994) The Vygotsky Reader. Oxford: Blackwell.

Warhurst, R (2011) Managers' practice and managers' learning as identity formation: Reassessing the MBA contribution. Management Learning 42(3): 261-278.

Watson, TJ (1996) How do managers think? Identity, morality and pragmatism in managerial theory and practice. Management Learning, 27(3): 323-341. 
${ }^{1}$ YouTube: Available at http://www.youtube.com/watch?v=qegtAuPLyEY. Also cited in Team Academy - trip to the wild west of management education (online article listed in references).

${ }^{2}$ JAMK is an abbreviation of Jyväskylän ammattikorkeakoulun. Ammattikorkeakoulun is Finnish for university of applied sciences.

${ }^{3}$ It is important to note that the Team Academy does not seek to delineate between between, or to define precisely, notions of 'management', 'leadership' and 'entrepreneurship'; all three conceptions, and their literatures, are potentially relevant.

${ }^{4}$ It is not our aim in this paper to evaluate the claims made by the Team Academy. We have reported claims that are made through public sources such as official websites and publicity materials.

${ }^{5}$ Kela is The Social Insurance Institution of Finland.

${ }^{6}$ Based on estimated total grant of $654,000 €$ (annual intake of 60 students, hence total student population in any one year of 180 students, multiplied by $3,600 €$ per student per year).

${ }^{7}$ There is no direct translation of this term. It is considered the equivalent of a knighthood.

${ }^{8}$ Such the 'Dragon's Den' [in the UK].

${ }^{9}$ Co-founder with Peter Senge of the Center for Organizational Learning at MIT in 1990.

${ }^{10}$ Team Academy pamphlet, Leading Thoughts, 2008-9. 